Published by LPMP Imperium

Journal homepage: https:/ / ejournal.imperiuminstitute.org/index.php/JMSAB

\title{
Analisis Dinamis Hubungan Antara Harga Saham dan Variabel Makroekonomi
}

Paulina

STIE Indonesia Banking School, Jakarta, Indonesia

\author{
Research Paper \\ Economics and Financial \\ Management
}

Received: 02 Feb 2021

Revised: 25 Feb 2021

Accepted: 3 Mar 2021

Online: 4 Mar 2021

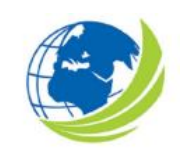

Jurnal Manajemen Strategi dan Aplikasi Bisnis, Vol 4, No. 1, 2021, pp. 77 - 90

eISSN 2655-237X
(C) The Author(s) 2021

DOI: https:// doi.org/ 10.36407/jmsab.v4i1.278

\section{7}

\begin{abstract} inflation, exchange rate, trade balance, industrial production index (histributed Lag (ARDL) study, we will look deeper into the dynamics of long-term and shortterm relationships for the aforementioned variables. The research period starts from January 2015 to December 2019, during which time there were many global upheavals that had a considerable impact on the Indonesian economy, through the ARDL model of interest rates, inflation, exchange rate, trade balance, industrial production index and stock prices are proven to have long-term cointegration or move together in the long term. But not only in the long run, these seven variables also have a dynamic short-term relationship that has a sufficient speed of adjustment towards equilibrium per month.
\end{abstract}

\section{Keywords:}

interest rate, inflation, exchange rate, trade balance, Autoregressive Distributed Lag Model

\section{Corresponding Author:}

Indonesia Banking School

Jl. Kemang Raya No. 35, Jakarta Selatan

Email: paulina.harun@ibs.ac.id

\section{(c) (2)}

CC BY: This license allows reusers to distribute, remix, adapt, and build upon the material in any medium or format, so long as attribution is given to the creator. The license allows for commercial use. 


\section{PENDAHULUAN}

Perkembangan ekonomi dunia yang semakin tinggi secara langsung ataupun tidak langsung akan berdampak kepada ekonomi setiap negara di dunia. Dampak ini disebabkan karena semakin terbuka ekonomi setiap negara, terutama pergerakan modal antar negara yang secara tidak langsung akan berdampak pada ekonomi negara tersebut.

Ekonomi global saat ini, dimana aktivitas ekonomi suatu negara tidak hanya terdampak dari sisi mikro bahkan dari sisi makro. Makroekonomi selama beberapa dekade sangat mempengaruhi aktivitas keuangan di suatu negara, hal ini sejalan dengan teori Arbritage Pricing Theory (APT) yaitu model penetapan harga aset multi-faktor berdasarkan gagasan bahwa pengembalian aset dapat diprediksi menggunakan hubungan linier antara pengembalian asset yang diharapkan dan sejumlah variabel makro ekonomi yang merespon risiko sistematis. Teori APT adalah salah satu model yang berguna untuk menganalisis portofolio dari sudut pandang nilai investasi, untuk mengidentifikasi sekuritas yang mungkin diberi peringkat sementara, Variabel makroekonomi dari waktu ke waktu akan berdampak pada investasi dan harga saham di pasar uang. Dalam beberapa waktu, perkembangan variabel makroekonomi di Indonesia dapat di lihat sebagai berikut : untuk nilai tukar, selama kurun waktu April 2019 hingga Maret 2020 mengalami fluktuasi yang cukup besar. Dimana April 2019 nilai tukar Indonesia terhadap US \$ berkisar di angka 14000 per US\$ sempat mengalami penguatan di Januari 2020 dan kembali melemah cukup tinggi di awal Maret 2020 sebagai dampak dari pandemi covid 19.

Demikian juga halnya dengan indeks produksi industri Indonesia selama beberapa kurun waktu mengalami fluktuasi yang cukup tinggi, dimana pada awal Maret 2019 mengalami angka indeks produksi industri yang cukup besar 7.920 dan pada Januari 2020 mencapai angka 0.813, suatu angka yang sangat rendah sekali dan ini tentunya akan berdampak pada harga saham di pasar uang. Variabel makroekonomi lainnya yang juga berdampak terhadap harga saham adalah investasi asing langsung (FDI). FDI akan berpengaruh terhadap harga saham hal ini disebabkan semakin banyak FDI yang masuk ke suatu negara akan berdampak positif terhadap harga saham di pasar uang. Variabel inflasi salah satu variabel makroekonomi yang juga mempengaruhi harga saham di pasar uang, dengan angka inflasi yang bervariasi dari waktu ke waktu juga akan memberikan dampak pada sektor produksi dan industri dan pada akhirnya terhadap harga saham sektor industri.

Beberapa model pendekatan yang dipergunakan untuk melihat perkembangan harga saham, yang sering di pergunakan adalah CAPM, dan APT. Beberapa hal yang menjadi kelebihan APT adalah faktor-faktor APT adalah risiko sistematis yang tidak dapat dikurangi dengan diversifikasi portofolio investasi. Faktor-faktor ekonomi makro yang telah terbukti paling dapat diandalkan sebagai prediktor harga termasuk perubahan tak terduga dalam inflasi, produk nasional bruto (GNP), spread obligasi korporasi dan pergeseran kurva hasil. Faktor lain yang umum digunakan adalah produk domestik bruto (PDB), harga komoditas, indeks pasar, dan nilai tukar. Berbeda dengan model penetapan harga aset modal, teori penentuan harga arbitrase tidak mengasumsikan bahwa investor memiliki portofolio yang efisien. Namun, teori ini mengikuti tiga asumsi mendasar: (1) Pengembalian aset dijelaskan oleh faktor sistematis. (2) Investor dapat membangun portofolio aset di mana risiko spesifik dihilangkan melalui diversifikasi. (3) Tidak ada peluang arbitrase di antara portofolio yang terdiversifikasi dengan baik. Jika ada peluang arbitrase, mereka akan dieksploitasi oleh investor.

Research Gap dalam penelitian ini adalah seberapa besar dampak variabel makroekonomi terhadap harga saham, dimana selama ini penelitian yang dilakukan melihat harga saham 


\section{Paulina}

Interest rate, inflation, exchange rate, trade balance, Autoregressive Distributed Lag Model

dengan menggunakan model CAPM dan fokus pada risiko yang dihadapi secara mikro, tetapi dengan menggunakan APT harga saham dapat dilihat sebagai dampak perubahan variabel makroekonomi atas risiko yang dihadapi harga saham tersebut, baik dalam jangka pendek maupun jangka panjang.

Penelitian sebelumnya berfungsi untuk analisa dan memperkaya pembahasan penelitian, serta membedakannya dengan penelitian yang sedang dilakukan. Dalam penelitian ini disertakan beberapa jurnal penelitian internasional sebelumnya yang berhubungan dengan harga saham dan variabel makro ekonomi. Chang et al. (2019) di Pakistan menujukkan pengaruh variabel makroekonomi terhadap harga saham. Hasil kesimpulan dengan metode ARDL neraca perdagangan, nilai tukar dan suku bunga berpengaruh negatif terhadap harga saham, sedangkan inflasi dan indeks produksi industri berpengaruh positif terhadap harga saham. Ajaz et al. (2017) menunjukkan adanya reaksi asimetris harga saham terhadap perubahan suku bunga dan nilai tukar secara full sample, serta sebelum krisis. Namun, tidak ditemukan asimetri pada periode pasca krisis.

Kebijakan moneter ketat tampaknya memperlambat harga saham, lebih dari kebijakan moneter mudah yang mendorong perubahan hraga saham. Fernandez et al. (2014), dengan menggunakan Model Probit untuk meramalkan kemungkinan pasar uang di IBEX 35 Spanyol, sebagai faktor penjelas yang dipilih dari serangkaian variabel ekonomi seperti kurva hasil di Spanyol, AS dan Eropa, beberapa variabel makro, dan berbagai indikator utama. Hasil menunjukkan bahwa kemiringan kurva imbal hasil AS dan Eropa memiliki beberapa konten informasi (tidak secara implisit hadir dalam kemiringan kurva imbal hasil Spanyol) yang membantu untuk memperkirakan probabilitas penurunan pasar dengan lebih baik. Humpe, dan Macmillan (2009), menggunakan analisis kointegrasi untuk melihat hubungan jangka panjang antara produksi industri, indeks harga konsumen, jumlah uang beredar, suku bunga jangka panjang, dan harga saham di AS dan Jepang. Untuk AS, ditemukan datanya konsistensi dengan vektor kointegrasi tunggal, di mana harga saham berhubungan positif dengan produksi industri dan berhubungan negatif dengan indeks harga konsumen dan suku bunga jangka panjang.

Bara et al. (2019), dengan menggunakan pendekatan model Autoregressive Distributed Lag (ARDL) dalam penelitian ini lebih dalam lagi melihat dinamika hubungan jangka panjang maupun jangka pendek untuk variabel nilai tukar Rupiah terhadap Dolar Amerika, BI Rate dan IHSG. Periode penelitian dimulai dari Juli 2005 sampai dengan Desember 2017, dimana dalam rentang waktu tersebut banyak terjadi pergolakan global yang memberikan dampak yang cukup besar terhadap Indonesia, salah satunya adalah pelemahan nilai tukar Rupiah terhadap Dolar Amerika. Dalam penelitian ini, melalui model ARDL nilai tukar Rupiah terhadap Dolar Amerika, BI Rate dan IHSG terbukti memiliki kointegrasi jangka panjang atau bergerak bersama - sama dalam jangka panjang. Namun tidak hanya jangka panjang, ketiga variabel tersebut juga mempunyai dinamika hubungan jangka pendek yang mempunyai kecepatan penyesuaian menuju keseimbangan yang cukup tinggi perbulannya.

\section{KAJIAN PUSTAKA}

\section{Efficienty Market Hypothesis}

Efficienty Market Hypothesis yaitu suatu pasar dimana nilai yang mencerminkan semua informasi yang tersedia dan cepat merespon pengumuman informasi baru, Keown et al, (2012), dalam Tandelilin (2017). Efisien atau tidaknya suatu pasar sangat tergantung pada seberapa cepat dampak suatu informasi yang tercermin pada harga surat-surat berharga. Pada pasar yang 
kurang efisien, harga surat-surat berharga kurang mencerminkan informasi yang ada (Tandelilin, 2017). Sedangkan pada pasar efisien, informasi akan secara cepat tercermin dalam surat-surat berharga sehingga tidak ada investor yang memiliki kesempatan untuk mendapatkan keuntungan yang besar. Teori efficienty market hypothesis memiliki tiga asumsi, yaitu (Shleifer, 2000):

1. Investor diasumsikan bersikap rasional sehingga menilai sekuritas secara rasional.

2. Terdapat beberapa investor yang tidak rasional, mereka melakukan perdagangan secara acak dan oleh karena itu saling membatalkan satu sama lain dan tidak mempengaruhi harga.

3. Investor yang tidak rasional akan bertemu dengan investor arbitrage yang bersikap rasional yang akan menghilangkan pengaruh mereka terhadap harga.

Fama (1970) dalam Tandelilin (2017) mengklasifikasikan bentuk pasar yang efisien kedalam tiga efficienty market hypothesis (EMH), sebagai berikut:

1. Efisiensi pasar dalam bentuk lemah (weak form)

Menjelaskan bahwa semua informasi dimasa lalu (historis) akan tercermin dalam harga saham sekarang. Informasi historis (harga dan volume perdagangan, serta peristiwa dimasa lalu) tidak dapat lagi digunakan untuk memprediksi perubahan harga dimasa mendatang karena sudah tercermin pada harga saat ini.

2. Efisiensi pasar dalam bentuk setengah kuat (semi strong)

Menjelaskan bahwa harga saham yang terbentuk sekarang mencerminkan informasi historis dan informasi yang dipublikasikan (earning, dividen, stock split, kesulitan keuangan yang dialami perusahaan). Suatu pasar dinyatakan setengah kuat jika infrormasi dapat direspon cepat oleh pasar (dalam satu hingga dua hari setelah pengumuman).

3. Efisiensi pasar dalam bentuk kuat (strong form)

Menjelaskan bahwa harga saham yang terbentuk sekarang mencerminkan informasi historis ditambah semua informasi yang dipublikasikan dan informasi yang tidak dipublikasikan. Pada pasar ini tidak akan ada investor yang mendapatkan abnormal return.

\section{Tingkat suku bunga terhadap harga saham}

Tingka suku bunga merupakan salah satu variabel makro yang cukup penting, dari beberapa studi yang dilakukan menunjukkan ada hubungan negatif antara tingkat suku bunga dengan harga saham, dan sedikit studi yang menunjukkan kecenderungan hubungan positif antara tingkat suku bunga dan harga saham. Menurut Efek Fisher, (Fisher, 1930), ekspektasi inflasi dan suku bunga nominal akan bergerak bersama-sama dan pergerakan suku bunga akan berdampak negatif terhadap harga saham melalui efek inflasi. Menurut Ratanapakorn dan Sharma (2007), biaya keuangan mengalami peningkatan sebagai akibat kenaikan tingkat suku bunga dan ini akan menurunkan profitabilitas perusahaan dan harga saham. Beberapa peneliti telah melakukan hal yang sama antara lain :

Suku bunga adalah harga yang harus dibayarkan oleh pihak yang memberikan pinjaman dana berdasarkan prinsip konvensional (Kasmir, 2012). Digunakan kebijakan yaitu BI Rate yang mempengaruhi suku bunga pasar uang, suku bunga deposito dan suku bunga kredit perbankan. (Ningsih \& Waspada, 2018).

Suku bunga dasar Bank Indonesia (BI Rate) dapat mempengaruhi kecenderungann pengambilan keputusan investasi oleh investor di dalam pasar saham Indonesia, oleh karena itu terdapat probabilitas bahwa tingkat suku bunga dasar Bank Indonesia akan mempengaruhi nilai 


\section{Paulina}

Interest rate, inflation, exchange rate, trade balance, Autoregressive Distributed Lag Model

IHSG (Ningsih \& Waspada, 2018). BI Rate berpengaruh berlawanan dengan IHSG. Jika BI Rate naik, IHSG akan turun dan sebaliknya (Tendelilin, 2001). Penelitian yang dilakukan sebelumnya membuktikan bahwa Hasil uji signifikan simultan yaitu Uji F, menunjukkan suku bunga secara simultan berpengaruh signifikan terhadap pergerakan IHSG (Dainara Abie Mahasasi, 2020). dan penelitian yang dilakukan oleh (Sri rahayu.2016.) membuktikan bahwa suku bunga berpengaruh positif terhadap Indeks Harga Saham sektor industri makanan dan minuman

H1 : Suku bunga berpengaruh negatif terhadap Indeks Harga Saham Sektor industri makanan dan minuman

\section{Inflasi terhadap harga saham}

Hubungan antara inflasi dan harga saham tidak konsisten, dari beberapa penelitian yang dilakukan Mukherje dan Naka (1995) dan Fama (1981) menunjukkan hubungan negatif diantara keduanya. Hal ini disebabkan kenaikan inflasi menciptakan ketidakpastian serta risiko yang ditanggung investor menjadi lebih tinggi, dan ini akan menyebabkan penurunan harga saham (Malkiel, 1979). Selain itu, kenaikan inflasi menyebabkan meningkatkan biaya produksi dan mengurangi aliran kas perusahaan dan pada akhirnya akan menurunkan harga saham. Sementara itu peneliti lainnya yaitu Nasseh dan Strauss (2000), Ibrahim (2003), Ibrahim dan Aziz (2003), inflasi memiliki hubungan positif terhadap harga saham.

Inflasi merupakan kecenderungan terjadinya peningkatan harga produk-produk yang beredar di masyarakat secara keseluruhan (Tendelilin, 2001). Indikator inflasi adalah CPI atau IHK. Inflasi merupakan salah satu faktor penyebab dari naik turunnya nilai harga saham karena naiknya harga barang yang beredar di masyarakat yang berdampak pada perekonomian. Tingginya tingkat inflasi mengakibatkan menurunnya daya beli masyarakat dan mengurangi pendapatan riil yang diterima oleh investor (Tandelilin, 2001) karena saat inflasi tinggi harga saham ikut meningkat. Penelitian sebelumnya membuktikan bahwa Inflasi berpengaruh positif dan signifikan terhadap Indeks Harga Saham Gabungan di Bursa Efek Indonesia (Rini Astuti, Joyce Lapian Paulina Van Rate, 2016). Dan penelitian yang dilakukan oleh (Satiri dan Augustina Kurniasih.2017). membuktikan bahwa inflasi berpengaruh positif terhadap Indeks Harga Saham Sektor industri makanan dan minuman

H2 : Inflasi berpengaruh positif terhadap Indeks Harga Saham Sektor industri makanan dan minuman

\section{Nilai tukar terhadap harga saham}

Fluktuasi nilai tukar uang sangat mempengaruhi investasi asing yang masuk di Indonesia. Hal terpenting dari nilai tukar rupiah adalah volatilitas nilai tukar rupiah tersebut. Volatilitas dari nilai tukar mata uang akan berdampak kepada pembiayaan kegiatan bisnis terutama perusahaan yang berorientasi ekspor dan impor. Pergerakan nilai tukar rupiah lebih ditentukan oleh faktor fundamental dan penguatan nilai tukar rupiah merupakan reaksi terhadap kondisi perekonomian global. Perubahan nilai tukar berpengaruh pada kegiatan operasional perusahaan, daya saing di pasar internasional dan sebagai konsekuensinya berdampak pada harga saham perusahaan tersebut. Pada level makro, dampak dari fluktuasi nilai tukar terhadap pasar modal tergantung dari kondisi ekonomi, perdagangan internasional dan ketidakseimbangan perdagangan dari negara tersebut. Pada level mikro, hubungan konseptual antara harga saham dan nilai tukar didasarkan pada daya saing perusahaan tersebut.

Fluktuasi nilai tukar secara substansial dapat memberikan pengaruh terhadap nilai perusahaan melalui perubahan persaingan, perubahan harga input, dan perubahan dalam nilai 
mata uang asing yang menjadi aset perusahaan. Nilai tukar Rupiah merupakan perbandingan nilai atau harga mata uang rupiah dengan mata uang lain. Dengan adanya perdagangan internasional, mata uang masing-masing negara perlu memiliki nilai perbandingan antar mata uang negara yang disebut sebagai kurs valuta asing atau kurs (Salvatore, 2008).

Nilai tukar dan harga saham memiliki hubungan positif (Mukherjee dan Naka ; 1995) serta (Soenen dan Hennigar ; 1988), hal ini disebabkan pada saat nilai tukar mengalami depresiasi akan meningkatkan kinerja harga saham domestik. Peningkatan nilai tukar meningkatkan investasi portofolio luar negeri dan akan mendorong perekonomian dalam negeri (Rahman dan Uddin ; 2009). Hasil analisis menunjukkan bahwa variabel nilai tukar rupiah secara parsial berpengaruh signifikan dan berhubungan negatif terhadap Indeks Harga Saham Gabungan (IHSG).

H3 : Nilai Tukar Rupiah berpengaruh positif terhadap Indeks Harga Saham sektor industri makanan dan minuman

\section{Neraca perdagangan terhadap harga saham}

Neraca perdagangan atau neraca ekspor-impor adalah perbedaan antara nilai ekspor dan impor suatu negara pada periode tertentu, diukur menggunakan mata uang yang berlaku. Neraca positif artinya terjadi surplus perdagangan jika nilai ekspor lebih tinggi dari impor, dan sebaliknya untuk neraca negatif. Setiap negara akan mempublikasikan laporan neraca perdagangan secara berkala, biasanya dalam tempo bulanan atau kuartalan. Hasilnya diamati oleh pemerintah, bank sentral, investor, spekulan, dan para pemain pasar lainnya sebagai bahan pertimbangan. Selain itu, kondisi surplus atau defisit juga bisa berdampak pada nilai tukar mata uang. Terdapat hubungan negatif antara neraca perdagangan dan harga saham (Abdullah dan Hayworth : 1993), meningkatnya neraca perdagangan akan meningkatkan profit perusahaan dan akhirnya meningkatkan harga saham. Demikian juga yang dilakukan Gay (2016), salah satu variabel makroekonomi yaitu neraca perdagangan berdampak terhadap harga saham.

H4 : Neraca perdagangan berpengaruh positif terhadap harga saham sektor industri makanan dan minuman

\section{Indeks produksi industri terhadap harga saham}

Indeks Produksi Industri merupakan indeks yang mengukur produksi negara melalui pertumbuhan manufaktur. Peningkatan indeks produksi industri memberikan sinyal pertumbuhan ekonomi yang baik yang menunjukkan kinerja perusahaan yang baik sehingga meningkatkan harga saham (Mahakud \& Kumari, 2015).

Berdasarkan pengujian dapat ditarik sebuah kesimpulan bahwa Indeks Produksi Industri dan inflasi berpengaruh positif terhadap kinerja IHSG (R Safiroh Febrina et al., 2018). Hal ini juga didukung oleh penelitian sebelumnya yang dilakukan oleh Kabir \& Masih (2014) yang menyatakan bahwa peningkatan pertumbuhan ekonomi negara akan meningkatkan produksi industri yang diikuti dengan peningkatan arus kas perusahaan sehingga harga saham meningkat. Terdapat hubungan postif antara indeks produksi industri dan harga saham (Abdullah dan Haywoth ; 1993), (Mukherjee dan Naka ; 1995), (Fama ; 1990). Demikian juga yang dilakukan Humpe dan Macmillan (2009), menunjukkan hubungan positif antara indeks produksi industri terhadap harga saham dan terjadi hubungan timbal balik antara keduanya.

H4 : IPI berpengaruh positif terhadap Indeks Harga Saham Sektor industri makanan dan minuman 
Paulina

Interest rate, inflation, exchange rate, trade balance, Autoregressive Distributed Lag Model

\section{METODE PENELITIAN}

Desain Penelitian

Penelitian tentang analisis dinamis variabel makroekonomi terhadap harga saham adalah penelitian deskriptif kuantitatif. Penelitian ini menggunakan objek penelitian adalah perusahaan yang publis di bursa efek indonesia khususnya industri makanan dan minuman dengan kurun waktu pengamatan selama Januari 2015 - Desember 2019.

\section{Populasi dan Sampel}

Populasi dari objek yang diteliti terdiri dari perusahaan pada sektor makanan dan minuman yang go public di BEI selama periode 2015 - 2019. Populasi tersebut berjumlah 30 perusahaan, dan metodepurposive sampling, dengan menggunakan kriteria sebagai berikut : (1) Merupakan perusahaan sektor makanan dan minuman yang go public di BEI; (2) perusahaan sektor makanan dan minuman masih tercatat sejak tahun 2015 - 2019 dengan data lengkap, Sehingga diperoleh 13 perusahaan sektor makanan dan minuman sebagai sampel penelitian

\section{Pengukuran Variabel}

Variabel yang digunakan dalam penelitian ini adalah variabel ekonomi (harga saham, nilai tukar, suku bunga, neraca perdagangan, inflasi dan indeks produksi industri), oleh karena itu pengukuran variabel menggunakan skala pengukuran rasio.

\section{HASIL DANPEMBAHASAN}

\section{Uji Stasioner (Unit Root Test)}

Hasil perhitungan uji stationer dengan menggunakan ADF di dapat nilai statsioner untuk variabel yang digunakan pada first difference yang dapat dilihat pada Tabel 2. di bawah ini.Secara keseluruhan menunjukkan bahwa seluruh variabel yang digunakan adalah stasioner sehingga data dapat digunakan untuk melakukan analisa jangka pendek dan jangka panjang.Uji stasioner yang dilakukan dengan menggunakan $\mathrm{ADF}$ test untuk semua variabel pada tingkat level tidak signifikan, oleh karena itu dilanjutkan pada tingkat first difference. Dari hasil uji ADF pada tingkat first difference semua variabel signifikan hal ini berarti semua variabel yang dipergunakan adalah stasioner.

Tabel 1.

Uji Unit Root

\begin{tabular}{|c|c|c|c|c|}
\hline Method & Statistic & Prob.** & $\begin{array}{c}\text { Cross- } \\
\text { sections }\end{array}$ & Obs \\
\hline \multicolumn{5}{|c|}{ Null: Unit root (assumes common unit root process) } \\
\hline Levin, Lin \& Chu t* & -33.6831 & 0.0000 & 7 & 5365 \\
\hline \multicolumn{5}{|c|}{ Null: Unit root (assumes individual unit root process) } \\
\hline Im, Pesaran and Shin W-stat & -39.1775 & 0.0000 & 7 & 5365 \\
\hline ADF - Fisher Chi-square & 578.200 & 0.0000 & 7 & 5365 \\
\hline PP - Fisher Chi-square & 439.584 & 0.0000 & 7 & 5446 \\
\hline
\end{tabular}

Sumber : Hasil olahan data

\section{Uji Asumsi Klasik}

Untuk melakukan model regresi, perlu dilakukan uji autokorelasi untuk mengetahui apakah nilai residu tergantung pada nilai residu sesudah atau sebelumnya dengan menggunakan tipe pengujian BG (Bruesch-Godfrey) serta uji heteroskedastitas untuk mengetahui apakah residu bersifat konstan atau tidak dengan menggunakan tipe pengujian Glejser. 


\section{Uji Autokorelasi}

Pada uji autokorelasi dengan menggunakan model OLS didapatkan hasil DW test sebesar 0.026858 yang mengindikasikan adanya autokorelasi. Unyuk menghindari adanya autokorelasi maka dilakukan perbaikan dengan menggunakan variabel baru yang telah disseuaikan dengan rho dan variabel lag (-1), dan hasilnya Durbin Watson Test sudah tidak menunjukkan adanya autokorelasi yaitu sebesar 2.399863 .

Uji Heteroskedastisitas

Dari hasil uji heteroskedastisitas di atas ternyata nilai probabilitas Obs*R-squared 0.9205>0.05, kesimpilannya tidak terjadi heteroskedastisitas.

Tabel 2.

Uji Heteroskedasticity

\begin{tabular}{lrll}
\hline Heteroskedasticity Test: Breusch-Pagan-Godfrey & \\
F-statistic & 0.32973 & Prob. F(6,773) & 0.9214 \\
Obs*R-squared & 1.9912 & Prob. Chi-Square(6) & 0.9205 \\
Scaled explained SS & 1.18461 & Prob. Chi-Square(6) & 0.9776 \\
\hline
\end{tabular}

Sumber : Hasil olahan data

Hasil pengolahan data pada tabel 3 dilihat bahwa dalam uji kointegrasi tingkat first difference menunjukan : Semua nilai trace statistic lebih besar dari nilai 0.05 critical value sehingga dapat disimpulkan variabel dependen dengan variabel independen lainnya saling memiliki sifat kointegrasi. Berdasarkan hasil pengujian tersebut dapat diketahui bahwa seluruhnya saling terkointegrasi pada derajat first difference.

\section{Tabel 3.}

Uji Kointegrasi

\begin{tabular}{|c|c|c|c|c|}
\hline \multicolumn{5}{|c|}{ Unrestricted Cointegration Rank Test (Trace) } \\
\hline Hypothesized & & Trace & $\begin{array}{c}0.05 \\
\text { Critical }\end{array}$ & \\
\hline No. of CE(s) & Eigenvalue & Statistic & Value & Prob.** \\
\hline None $*$ & 0.541842 & 1598.389 & 125.6154 & 1.0000 \\
\hline At most $1 *$ & 0.396766 & 993.4702 & 95.75366 & 0.0001 \\
\hline At most $2 *$ & 0.258416 & 601.7469 & 69.81889 & 0.0001 \\
\hline At most $3 *$ & 0.213059 & 370.0476 & 47.85613 & 0.0001 \\
\hline At most $4 *$ & 0.126897 & 184.3558 & 29.79707 & 0.0001 \\
\hline At most $5 *$ & 0.094540 & 79.18724 & 15.49471 & 0.0000 \\
\hline At most 6 & 0.002860 & 2.220002 & 3.841466 & 0.1362 \\
\hline \multicolumn{5}{|c|}{$\begin{array}{l}\text { Trace test indicates } 6 \text { cointegrating eqn(s) at the } 0.05 \text { level } \\
* \text { denotes rejection of the hypothesis at the } 0.05 \text { level } \\
\text { **MacKinnon-Haug-Michelis (1999) p-values }\end{array}$} \\
\hline
\end{tabular}

Sumber : Hasil olahan data 


\section{Paulina}

Interest rate, inflation, exchange rate, trade balance, Autoregressive Distributed Lag Model

\section{Hasil Uji Error Correction Model (ECM)}

Dari hasil uji ECM diatas dapat disimpulkan bahwa nilai probabilitas RES(-1) sebesar 0.0393 lebih kecil dari nilai probabilitas C yaitu 0.539 dan nilai coefficient RES(-1) menunjukan angka -0.01187 yang artinya model analisa ECM dapat dilanjutkan.

Tabel 4.

Hasil Perhitungan Model ECM

\begin{tabular}{ccccc}
\hline Variable & Coefficient & Std. Error & t-Statistic & Prob. \\
\hline C & 0.002687 & 0.008569 & 0.313574 & 0.7539 \\
RES(-1) & -0.011875 & 0.005752 & 2.064364 & 0.0393 \\
\hline
\end{tabular}

Sumber : Hasil olahan data

Hasil perhitungan ECM di atas dapat dilihat pada persamaan berikut :

$$
\begin{gathered}
\Delta S P t=0.0027+0.072 \Delta I R t++0.002 \Delta I N F t-0.808 \Delta E R t++0.002 \Delta T B t++0.457 \Delta I P I_{B t} \\
*-0.012 \Delta I P \bar{i}_{F t} *-0.012 R E S(-1)
\end{gathered}
$$

Berdasarkan nilai speed of adjusment terdapat $1.2 \%$ ketidakseimbangan,pada pengaruh jangka pendek Irt, INFt, Ert, TBt, IPI_Bt, dan IPI_Ft terhadap SPt yang terkoreksi setiap periodenya.

\section{Uji Lag Optimum}

Panjang nilai lag optimal pada masing-masing kriteria yaitu AIC dan SIC adalah lag yang memiliki nilai kriteria minimum. Berdasarkan pada tabel 6 tersebut, menunjukkan bahwa nilai schwarz information criterion (SC) memiliki nilai terendah yang Oleh karena itu lag optimal=1

Tabel 5.

Hasil Uji Lag Optimum

\begin{tabular}{cccccc}
\hline Lag & LogL & LR & FPE & AIC & SC \\
\hline 0 & 1674.95 & NA & $3.05 \mathrm{e}-11$ & -4.3492 & -4.306919 \\
1 & 4314.44 & $5223.91 *$ & $3.55 \mathrm{e}-14^{*}$ & $-11.1041^{*}$ & $-10.7651 *$ \\
\hline
\end{tabular}

Sumber : Hasil olahan data

\section{Model ARDL}

Dari hasil perhiungan model ARDL, dapat dilihat pada Tabel 5 di bawaha ini, menunjukkan dalam jangka pendek dapat disimpulkan bahwa nilai CointEq $=-0.011732$ dengan probabilitas 0.0416 artinya terjadi kointegrasi dalam model tersebut. Nilai beta CointEq yang negatif menunjukan bahwa model akan menuju keseimbangan dengan kecepatan $1.17 \%$ perbulan. Dalam jangka pendek nilai tukar berpengaruh negative signifikan terhadap harga saham sektor makanan dan minuman, hal ini sesuai dengan penelitian Chang et al. (2019); Ajaz et al. (2017). Sedangkan untuk variable indeks produksi industri minuman berpengaruh positif signifikan terhadap harga saham, sesuai dengan hasil penelitian Chang at all (2019); Humpe and Macmillan (2009).

Melalui pendekatan ARDL kita juga dapat memperoleh estimasi jangka pendek yang dapat dilihat melalui nilai ECT atau CointEq. Melalui hasil uji kointegrasi pada tabel 4.7. diketahui bahwa nilai CointEq(-1) $=-0.011732$ dan signifikan pada level 5\%, yang berarti terjadi kointegrasi jangka pendek dalam model ini. Koefisien CointEq selanjutnya akan digunakan untuk mengukur speed of adjustment yang merupakan kecepatan penyesuaian dalam merespon 
terjadinya perubahan. Nilai ECT atau CointEq valid jika koefisien bernilai negative dengan probabilitas signifikan pada level 5\%. Pada penelitian ini, model ARDL $((1,0,0,1,0,1,0)$ memenuhi persyaratan validitas tersebut, sehingga dalam penelitian ini kita dapat menyimpulkan bahwa model akan menuju pada keseimbangan dengan kecepatan 1.1\% perbulan.

Tabel 6.

Hasil Perhitungan Model SRDL

\begin{tabular}{|c|c|c|c|c|}
\hline \multicolumn{5}{|c|}{ Cointegrating Form } \\
\hline Variable & Coefficient & $\begin{array}{r}\text { Std. } \\
\text { Error }\end{array}$ & $\begin{array}{r}\mathrm{t}- \\
\text { Statistic }\end{array}$ & Prob. \\
\hline D(IRT_ I) & -0.077 & 0.071 & -1.082 & 0.279 \\
\hline D(INFT I) & 0.002 & 0.010 & 0.242 & 0.809 \\
\hline D(ERT I) & -0.855 & 0.376 & -2.272 & 0.023 \\
\hline $\mathrm{D}(\mathrm{TBT} \mathrm{I})$ & 0.005 & 0.003 & 1.436 & 0.151 \\
\hline D(IPI BT I) & 0.499 & 0.137 & 3.645 & 0.000 \\
\hline D(IPI_FT I) & -0.126 & 0.183 & -0.692 & 0.489 \\
\hline CointEq(-1) & -0.012 & 0.006 & -2.041 & 0.042 \\
\hline $\begin{array}{c}\text { Cointeq }=\text { SPT_ I - }(-6 \\
0.4034 * \text { TBT I }+1 .\end{array}$ & $\begin{array}{l}.2090 * \mathrm{INFT} \\
-10.7733 * \mathrm{IP}\end{array}$ & $\begin{array}{l}-33.248 \\
\Gamma \mathrm{I}-250\end{array}$ & $\begin{array}{l}* \text { ERT_ I + } \\
2476)\end{array}$ & \\
\hline
\end{tabular}

Sumber : Hasil olahan data

Kriteria pemilihan lag secara otomatis telah dilakukan oleh Eviews. Kriteria dengan nilai AIC terkecilah yang paling baik dari 20 model terbaik yang ditawarkan oleh kriteria AIC. Kriteria yang terpilih adalah ARDL $(1,0,0,1,0,1,0)$ artinya Harga Saham sektor industri makanan dan minuman berjumlah 1 lag,tingkat suku bunga 0 lag, inflasi 0 lag, nilai tukar 1 lag, neraca perdagangan 0 lag dan IPI minuman 1 lag dan IPI makanan 0 lag.

\section{Cusum dan Cusum Q}

Dari hasil uji CUSUM dan CUSUMQ test, dapat dilihat bahwa model dalam keadaan kurang stabil karena garis cusum sq berada diluar garis signifikan 5 persen (merah), dapat dilihat pada grafik 1.

\section{Bound Test}

Uji Bounds dilakukan untuk menguji adanya long-run association dalam model ARDL yang terpilih. Hasil dari Bounds test ini akan lebih menitikberatkan pada nilai F statistic. Nilai Fstatistic akan dibandingkan dengan besaran critical value pada level 5\%, yang juga telah disediakan oleh Eviews. Apabila F-statistic mempunyai nilai yang melebihi upper Bounds value maka null hypothesis yang menyatakan bahwa tidak terjadi long-run association ditolak, yang artinya variabel - variabel dalam penelitian bergerak bersama - sama dalam jangka panjang. 


\section{Paulina}

Interest rate, inflation, exchange rate, trade balance, Autoregressive Distributed Lag Model

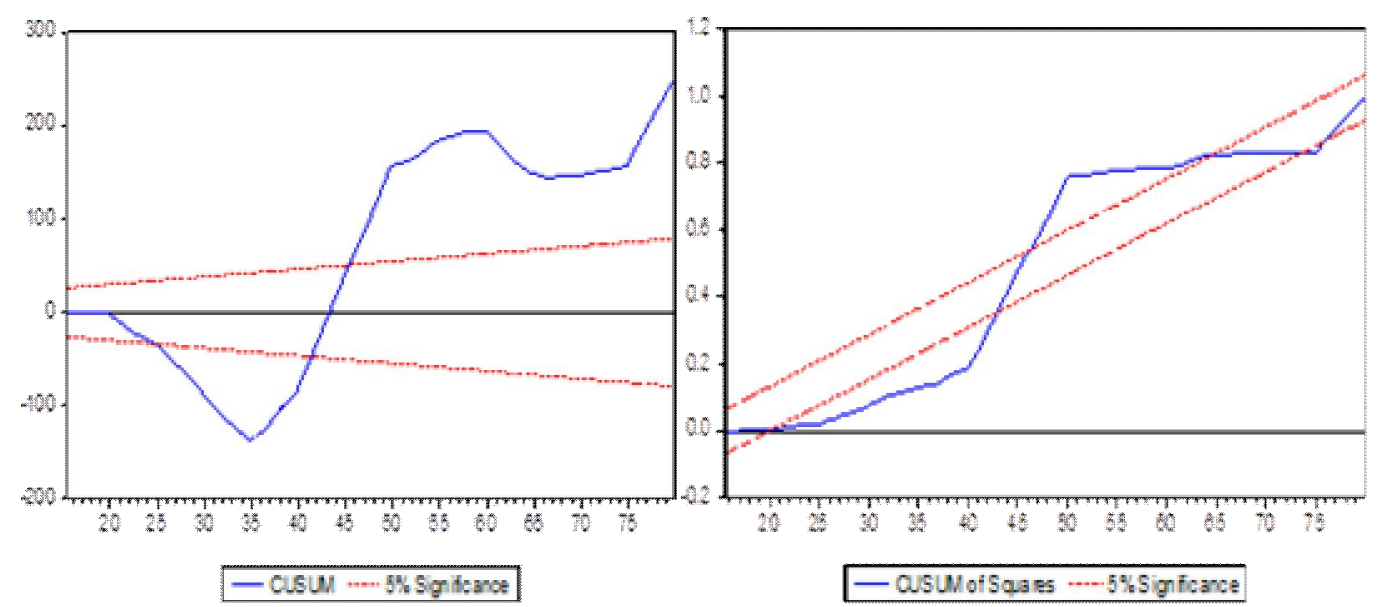

Gambar 1.

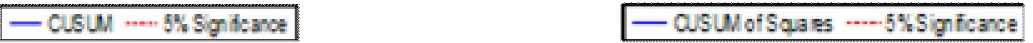

\section{CUSUM dan CUSUMQ test}

Berdasarkan hasil Bounds Test untuk model ARDL $((1,0,0,1,0,1,0))$ pada tabel 7 , terlihat bahwa nilai F-statistic model adalah 0.864015 . lebih kecil dari nilai upper bound pada level 5\%, bahkan masih juga lebih kecil dibandingkan dengan upper bound pad level 2,5\%. Null hypothesis diterima, berarti tidak terjadi long-run association, hal ini menunjukkan bahwa ketujuh variabel dalam penelitian ini yaitu tingkat suku bunga, inflasi, nilai tukar rupiah, neraca perdagangan, indeks produksi industri makanan dan minuman tidak terjadi kointegrasi dalam jangka panjang atau bisa dikatakan bahwa ketujuh variabel tersebut tidak bergerak bersama sama dalam jangka panjang.

\section{Tabel 7.}

Bound Test

ARDL Bounds Test

Included observations: 779

Null Hypothesis: No long-run relationships exist

\begin{tabular}{lcc}
\hline \hline Test Statistic & Value & $\mathrm{k}$ \\
\hline \hline F-statistic & 0.864015 & 6 \\
\hline \hline \multicolumn{2}{l}{ Critical Value Bounds } & \\
\hline \hline Significance & I0 Bound & I1 Bound \\
\hline \hline $10 \%$ & 2.12 & 3.23 \\
$5 \%$ & 2.45 & 3.61 \\
$2.5 \%$ & 2.75 & 3.99 \\
$1 \%$ & 3.15 & 4.43 \\
\hline \hline
\end{tabular}

Sumber : Hasil olahan data

\section{Implikasi Praktis/ Teoritis}

Dalam jangka pendek, variable nilai tukar dan indeks produksi industry sector minuman berpengaruh terhadap harga saham, hal ini mengindikasikan bahwa dalam jangka pendek kebijakan yang harus dilakukan pemerintah adalah menjaga nilai tukar dalam batas-batas 
tertentu, sehingga dalam fluktuasi nilai tukar rupiah tidak menimbulkan efek negative terhadap pertumbuhan sektor industri makanan dan minuman, hal ini dimungkinkan karena beberapa komponen industri tersebut masih di datangkan dari luar (impor), stabilitas nilai tukar dari waktu ke waktu sangat diharapkan bisa dijaga dengan kebijakan pemerintah baik dari sisi permintaan maupun penawaran nilai tukar. Sementara itu dalam jangka panjang, untuk mengurangi ketergantungan dengan komponen impor, pertumbuhan sektor industri makanan dan minuman kebijakan yang dapat dilakukan pemerintah adalah mengutamakan penggunaan komponen dalam negeri melalui ketersediaan bahan baku dengan cara mengembangkan industri hulu.

\section{KESIMPULAN}

Dari hasil perhitungan yang dilakukan terdapat beberapa kesimpulan berikut : pertama, Penelitian ini bertujuan untuk melihat dinamika hubungan antara tingkat suku bunga, inflasi, nilai tukar rupiah, neraca perdagangan indeks produksi industri makanan dan minuman, serta harga saham, menggunakan pendekatan Autoregressive Distributed Lag (ARDL). Penelitian terutama fokus pada periode Januari 2015 sampai dengan Desember 2019 dimana dalam periode tersebut terjadi beberapa kali perubahan dalam ekonomi global. Dalam beberapa kesempatan Pemerintah Indonesia menggunakan mekanisme menaikkan tingkat suku bunga acuan atau BI Rate untuk menahan depresiasi Rupiah, dan beberapa waktu memang cukup berhasil. Pelemahan atau penguatan nilai tukar dan mekanisme perubahan tingkat suku bunga acuan juga dipercaya akan memberikan dampak terhadap pasar modal yang dalam hal ini akan dicerminkan melalui harga saham gabungan perusahaan makanan dan minuman yang listed.

Kedua, melalui pendekatan model ARDL, dalam penelitian ini diketahui bahwa pada periode Januari 2015 - Desember 2019 pergerakan nilai tukar dan indeks produksi industri minuman berpengaruh terhadap harga saham. Nilai tukar Rupiah terhadap Dolar Amerika, dan indeks produksi industri minuman terbukti tidak memiliki kointegrasi jangka panjang atau bergerak bersama - sama dalam jangka panjang. Namun dalam jangka pendek, variabel bebas yang dipergunakan berkointegrasi satu sama lain. Dinamika hubungan jangka pendek yang mempunyai kecepatan penyesuaian menuju keseimbangan yang cukup tinggi sampai $1.1 \%$ tiap bulannya. Seluruh kondisi ini menunjukkan bahwa variabel makroekonomi dan kebijakan moneter yang diambil harus selalu memperhatikan dampaknya terhadap sektor keuangan terutama pasar modal, karena saling berhubungan dan mempengaruhi.

Kajian yang dilakukan ini masih memiliki keterbatasan, yautu : (1) tidak memasukkan variabel investasi pada sektor makanan dan minuman, hal ini tidak dilakuakan karena data investasi bulana pada sketor makanan dan minuman tidak lengkap. (2) beberapa data khsususnya varaibel inflasi dan neraca perdagangan menggunakan data umum dan tidak khsusus untuk sektor makanan dan minuman. Adapun saran yang dapat diajukan dari hasil penelitian ini antara lain: (1) bagi peneliti selanjutnya dapat menambahkan varaibel makroekonomi lainnya seperti variabel investasi, inflasi pada sektor tertentu dan bukan secara umum. (2) Menggunakan model Two Stage Least Square (TSLS) untuk melihat hubungan kausalitas antar variabel (3) Bagi investor hasil kajian ini diharapkan dapat menjadi perimbangan dalam mengambil keputusan berinvstasi pada sektor indusri makanan dan minuman.

\section{REFERENSI}

A.A.M.D. Amarasinghe.(2016). A study on the impact of industrialproduction index (IPI) tobeverage, food and tobacco sectorindex with special reference to Colombo Stock 
Paulina

Interest rate, inflation, exchange rate, trade balance, Autoregressive Distributed Lag Model

Exchange. International Conference of Sabaragamuwa University of Sri Lanka 2015 (ICSUSL 2015).

Abdullah, D,A., and Hayworth, S.C (1993), Macroeconomics of stock price fluctuations, Quarterly Journal of Business and Economics, Vol. 32 No. 1 pp 50-67

Ajaz, T, Nain, MZ., Kamaiah, B and Sharma, N.K (2017), Stock prices, exchange rate and interest rate : evidence beyond symetry, Journal of Business and Management, Vol. 5 No. 12, pp.6273

Astuti, Rini, Lapian Joyce, Van Rate Paulina. (2016). Pengaruh Faktor Ekonomi Terhadap Indeks Harga Saham Gabungan (IHSG) di Bursa Efek Indonesia (BEI). Periode 2006 - 2015. Jurnal Berkala Ilmiah Efisiensi. Vol. 16 No. 02 Tahun 2016.

Badan Pusat Statistik, Data Ekonomi, Beberapa Edisi

Boediono. (2014). Seri Sinopsis Pengantar Ilmu - No. 5 Ekonomi Makro. Yogyakarta: BPFE.

Brigham, E. F., \& Houston, J. F. (2012). Fundamentals of Financial Management. United States: South-Western Cengage Learning.

Chang, B,H.,Meo, et all (2019), Dynamic analysis of the relationship between stock prices and macroeconomic variables : An empirical study of Pakistan stock exchange South Asian Journal of Business Studies, Vol. 8 No. 3, 2019. Pp.229-345

Fama, E.F (1981), Stock returns, real activity, inflation, and monrey, The American Economic Review, Vol. 71 No. 4, pp 545-565

Gay, RD (2016), Effect of Macroeconomics variables on stock market returns for four emerging economics : Brazil, Russia, India, and China, The International Business \& Economics Research Journal (online), Vol. 15 No.3 pp.119-126

Gujarati, D. (2012). Econometrics by Example. New York: Pargrave Macmilan.

Humpe, A. and Macmillan, P (2009), Can macroeconomic variables explain long term stock markets movements ? A comparison of the US and Japan, Applied Financial Economics, Vol. 19 No. 2, pp.111-119

Judisseno, Rimsky K. (2002). Sistem Moneter dan Perbankan di Indonesia. Jakarta: Gramedia Pustaka Utama.

Kuosmanen, P., Nabulsi, N, and Vataja, J (2015), Financial variables and economic activity in the Nordic countries, International Review of Economics \& Finance, Vol. 37, pp. 368 - 379

Mishkin, Frederic S. (2008). Ekonomi Uang, Perbankan, dan Pasar Keuangan. Jakarta: Salemba Empat.

Mukherjee, T.K, and Naka, A (1995), Dynamic relations between macroeconomic variables and the Japanese stock market an application of a vector error correction model, Journal of Financial Research, Vol. 18 No. 2, pp. 223-237

Ningsih, Meidiana., Waspada, Ikaputra.(2018). Pengaruh BI Rate dan Inflasi Terhadap Indeks Harga Saham Gabungan (Studi Pada Indeks Properti, Real Estate, Dan Building Construction, di BEI Periode 2013 - 2017). Jurnal Manajerial. Vol. 17. DOI : 10.17509/ manajerial.v17i2.116 4

Shawtari, Fekri Ali, Milad Abdelnabi Salem, Hafezali Iqbal Hussain, Weni Hawariyuni, and A. Thabet Omer. (2016). "Long Run Relationship between Macroeconomic Indicators and Stock Price: The Case of South Africa." Journal of Internet Banking and Commerce 21.

Tandelilin, E. (2017). Portofolio dan Investasi: Teori dan Aplikasi. Yogyakarta: Kanisius.

Zaretta, Bara; Yovita, Lenni. (2019). Harga Saham, Nilai Tykar, dan Tingkat Suku Bunga Acuan Dalam Model Autoregressive Distributed Lag (ARDL). Jurnal Penelitian Ekonomi dan Bisnis,4(1), 2019,Hal:9-22 


\section{Declarations}

\section{Funding}

The authors received no financial support for the research and publication of this article.

\section{Conflicts of interest/ Competing interests:}

The authors have no conflicts of interest to declare that are relevant to the content of this article.

Data, Materials and/ or Code Availability:

Data sharing is not applicable to this article as no new data were created or analyzed in this study.

\section{How to cite this Article}

Harun, P. (2021). Analisis Dinamis Hubungan Antara Harga Saham dan Variabel Makroekonomi. Jurnal Manajemen Strategi Dan Aplikasi Bisnis, 4(1), 77 - 90 